\title{
HOW FIXED ARE CLASS SHAREHOLDER RIGHTS?
}

\author{
George D. Gibson*
}

I

The Rise and Fall of Vested Rights

"Hereupon is to be collected divers diversities." These related, in the original text, to the feudal law of land. "Apt words of limitation are quamdiu, dummodo, dum, quousque, durante \&c. ..."2 However apt these words may have been, they seem out of fashion today. Similar changes have occurred in class shareholder rights, and the old words of "vested rights" now. seem equally out of fashion. Such rights are now "fixed" only in the sense that they continue until changed by the vote of a specified majority in the manner provided by statute.

Throughout the nineteenth century, land remained the principal form of property. It was natural, therefore, for judges, being students of tradition and for the most part freeholders as well, to approach new forms of property with a solid respect for the principles of real estate law. This was no less true where the issue involved a group of people, as when Leicester Square was set apart by its owner as a "square garden" for the use of all those to whom he sold nearby lots. ${ }^{3}$ They were still a small group, and their interests were intensely tangible and personal. It was natural, therefore, as in the case of partnerships, for the courts to require unanimous consent for any substantial change of specified participations.

Corporation law in the modern sense was unknown, apart from limited exceptions in New York, until about $1835 .^{4}$ From then on, general acts were adopted with increasing frequency to permit incorporation through standardized procedure without need of special legislative act. By the middle of the century, this had become the customary method of incorporation. But the corporation was still viewed as a mere legal form attributed to a group of individuals, usually a limited group, for the promotion of some particular enterprise. The enterprise itself was limited and not so very different from a "square garden" or a partnership. Indeed, the law was clearly concerned with imposing effective limits on the scope and duration of the

- B.A. 1924, University of Virginia; A.M. 1925, LL.B. 1928, Harvard University. Member of the Virginia bar. Member, Committee on Corporate Laws, American Bar Association; Secretary, Section of Corporation, Banking, and Business Law, American Bar Association.

${ }^{1}$ Co. LITT. $2 \times 4$ b (1809).

${ }^{2}$ Mary Portington's Case, to Co. 35 b, 41 b, 77 Eng. Rep. 976, 985 (K.B. 1613 ).

${ }^{3}$ Tulk v. Moxhay, 2 Ph. 774, 4I Eng. Rep. II 43 (Ch. 1848). See also The Duke of Bedford v. The Trustees of the British Museum, 2 My. \& K. 552, 39 Eng. Rep. ro55 (Ch. 1822).

- See Dodd, American Business Association Law a Hundred Years Ago and Today, in 3 LAw: A Century of Progress 1835-1935, 254, 271, 273, 289 (I937); Adolph A. BerLe, JR., and Gardiner C. Menns, The Modern Corporation and Private Property r36 (r932). 
undertaking. ${ }^{5}$ A definite time limit was usually imposed on the continuation of the corporate existence. The powers that might be exercised were sparingly enumerated, rather than by general grant. The incorporators or directors were often required to be residents of the domiciliary state. There was no power to hold stock in other corporations. And all of these limitations were enforced with a strict eye. This may reflect an uneasy recollection of the vast holdings of property by the Church in England, and, indeed, in all of Europe, until the sixteenth century. But in any event, the policy of restraint is clear.

If we say that America's greatest need at the end of the eighteenth century was political independence from Europe, we may equally agree that her greatest need in the second half of the nineteenth century was the multiplication of property. New means were provided by the techniques of the industrial revolution. New necessities were presented in the subjugation of the continental wilderness, which was a supreme opportunity and challenge. Throughout this period, accordingly, and for another third of a century as well, the aspects of property received special veneration. The social need combined with feudal tradition for this result. The astonishing advances in material prosperity that ensued made it easy to accept the supremacy of property as a natural and sufficient postulate.

This postulate received some of its most striking illustrations in court decisions on attempts to amend corporate charters. Rules of feudal rigidity were built up on the basis of a prior decision that had been rendered in a different context with regard to Dartmouth College.

Before the days of the American business corporation, the Supreme Court had been faced by an attempted appropriation of an institution established in corporate form by royal charter. The Trustees of Dartmouth College were entitled by charter to appoint their own successors in perpetuity. On this basis, considerable sums had been bequeathed them by Lord Dartmouth for the "education of the American savages." After the Revolution, it occurred to New Hampshire that a more agreeable scheme would be for all the Trustees to be appointed by the Governor. So, it adopted an act purporting to amend the charter to this effect. This attempt to "nationalize" the control of Dartmouth was, in some respects, similar to the Egyptian expropriation of the Suez Canal. The change, intensely simple, was one by which "the will of the state is substituted for the will of the donors, in every essential operation," and, in consequence, the "system is totally changed" so as to be "subversive of that contract." The Supreme Court held this invalid under the Federal Constitution. ${ }^{8}$ No such difficulties would exist, Mr. Justice Story added in his concurring opinion, if "a power be reserved for this purpose" of later amend-

${ }^{5}$ See Louis K. Liggett Co. v. Lee, 288 U.S. $5 \times 7$ (1933).

- Trustees of Dartmouth College v. Woodward, I7 U.S. (4 Wheat.) $5 \times 8$ (1819).

${ }^{7} 7 d$. at $652-53$.

${ }^{8}$ This was under the contracts clause, U.S. ConsT. art. I, $\S$ xo, cl. 1, but the same result was later reached under the due process clause. Id., amend. XIV, \$ I. See Smyth v. Ames, I6g U.S. 466, 522, 526 (1898). (dictum). But see Munn v. Illinois, 94 U.S. II3 ( 1877 ). 
ment. ${ }^{9}$ This cue was immediately followed by many states, and such reservations of power became customary.

As a simple matter of common sense, one would have supposed that the reservation of unlimited power of amendment of corporate charters would have made, as it was no doubt intended to do, the Dartmouth College case wholly inapplicable in subsequent corporation law. But judges seek what they think the country needs most. With feudal recollections and guided by the dominant role of property in augmenting the American empire at that time, the judges set about to find "divers diversities" that might limit and defeat the reserved power of amendment. First, they extended the underlying premise of the Dartmouth College case. As decided, it did not involve a change by majority vote of the owners. Rather, it involved a state seizure of control of a private institution and its property. For all that, it was now extended so that, as in the case of realty and partnerships, the shareholder's interest, however defined in the charter, was constitutionally immune from any substantial change, except by his individual consent.

This made it necessary to inquire whether there had been "consent" in each particular case. The concept of consent comes from the law of private contracts. It is not an altogether easy matter to determine when there has been a meeting of minds between two men. It is decidedly more complicated to determine when there has been a meeting of minds between an individual investor and the sovereign, who can be found only in shifting groups of spokesmen and often enough expresses his will in Delphic phrases that become precise only with the slow elucidation of experience. But it is natural to deal with a new problem in terms of accepted tradition. There could be little doubt that consent is given if the power to amend on the assent of a stipulated majority was proclaimed in terms in the charter. If a purchaser assents to anything, he assents to that. ${ }^{10}$ But there should be no more doubt where the right is reserved in the code or constitution of the domiciliary state. While these are more difficult to locate and often to understand, it is elemental that the law of the state at the time of issuing the charter is a part of the charter as fully as if printed in the text of the charter itself. ${ }^{11}$ It would seem to follow, therefore, as the modern cases hold, that there can be no impairment of contracts, and no taking of property, where the right to make the amendment is reserved by law. ${ }^{12}$

But for a long time, it was not so simple. The elaboration of the "consent" doctrine led to many scholarly "diversities." One line of cases held that the power

${ }^{\circ}$ 7. U.S. (4 Wheat.) at 675 .

${ }^{10}$ Western Foundry Co. v. Wicker, 403 Ill. 260, 85 N.E.2d 722 (r949).

${ }^{11}$ De Mello v. Dairyman's Co-Operative Creamery, 73 Cal. App. 2d 746, r67 P.2d 226 (r946); Bcloff v. Consolidated Edison Co. of N.Y., 300 N.Y. xI, 87 N.E.2d 56x (x949); Franzblau v. Capital Securities Co. 2 N.J. Super. 5I7, 64 A.2d 644 (Ch. I949); Sherman v. Pepin Pickling Co., 230 Minn. 87, 4I N.W.2d 57x (1950); Midland Truck Lines, Inc. v. Atwood, 362 Mo. 397, 24I S.W.2d 903, 904-05 (I951); Opdyke v. Security Savings \& Loan Co., I57 Ohio St. I2I, I05 N.E.2d 9 (1952); In re Mayellen Apartments, 134 Cal. App. 2d 298, 285 P.2d 943 (x955).

${ }^{10}$ McNulty v. W. \& J. Sloane, 184 Misc. 835, 54 N.Y.S.2d 253 (Sup. Ct. 1945); Donohue v. Heuser, 239 S.W.2d 238, 24I (Ky. I95r). 
of amendment reserved by statute should be so narrowly read as to include only those aspects of the corporate charter affecting relations with the state and, thus, to have no bearing at all on any proposed change of the class shareholder rights. ${ }^{18}$ As far as corporate readjustments were concerned, the result was the same as if there had been no reserved power at all and hence no "consent." A second line of cases held that even if the legislative authorization for charter changes dealt unmistakably with changes of class right, still it would not be applied to any particular change unless that particular change was itemized specifically in the statute. If some other name could be found for the change, as the resources of the bar and bench ordinarily permit, it was held beyond the reserved power. It was quite plain that when the judges considered property rights to be in risk, they would not listen to the legislature if they could find any way to avoid it. And, of course, they generally could. For example, although the Delaware legislature reserved the power for any alteration of "preference" upon a majority assent of the adversely-affected class, the Delaware courts held that accrued dividends of preferred stock were a "vested right" rather than a "preference" and, thus, beyond the scope of the reserved power." A third line of cases held that even if the reserved power was unmistakably clear and unassailably specific, nevertheless, it would not be applied to stock issued prior to the enactment of the statute. ${ }^{10}$

The flood tide of this judicial preoccupation with the fixed rights of private property, as well as its turn and ebb, can be found in the treatment given the Delaware legislation of 1927 broadening its amendment statute to include all "special rights" as well as "preferential rights." This was generally understood to permit the elimination of preferred arrears. ${ }^{16}$ Many transactions were accomplished on that premise. But then the Delaware Supreme Court unexpectedly held the new words inapplicable to previously-issued stock. ${ }^{17}$ The "vested rights" doctrine, however, had outlived its usefulness. Soon afterwards, the Delaware court found a way to permit changes to be made without regard to the calendar. It would uphold them so long as they were accomplished through the formal variant of a merger, even with a wholly owned subsidiary. ${ }^{18}$

In retrospect, it is now apparent that this marked the end of "vested rights,"

${ }^{13}$ For this result, a philosophy was presupposed by which a corporate charter is simultaneously three contracts: (1) a contract among the shareholders, (2) a contract between the shareholders and the corporation, and (3) a contract between the corporation and the state. See, e.g., Pronik v. Spirits Distributing Co., 58 N.J. Eq. 97, 42 Atl. 586 (Ch. I899). State reservation statutes have all been interpreted as applying to corporate charters in so far as they are contracts between the corporation and the state.

${ }_{14}$ Morris v. American Pub. Util. Co., I4 Del. Ch. 136, 122 Atl. 696 (Ch. 1923).

${ }^{16}$ E.g., Yoakam v. Providence Biltmore Hotel Co., 34 F.2d 533 (D. R.I. 1929).

${ }^{10}$ See Harr v. Pioneer Mechanical Corp., 65 F.2d 332 (2d Cir. 1933), cert. denied, 290 U.S. 673 (1933).

${ }_{17}$ Keller v. Wilson \& Co., 2I Del. Ch. 39r, 190 Atl. I15 (Sup. Ct. 1936).

${ }^{18}$ Federal United Corp. v. Havender, 24 Del. Ch. 318, 11 A.2d 331 (Sup. Ct. 1940); Porges v. Vadsco Sales Corp., 27 Del. Ch. 127,32 A.2d 148 (Ch. 1943). And see Langfelder v. Universal Laboratories, Inc., 68 F. Supp. 209 (D. Del. I946), $a f^{\prime} d$, 163 F.2d 804 (3d Cir. 1947); Hottenstein v. York Ice Mach. Corp., 136 F.2d 944 (3d Cir. 1943), cert. denied, 325 U.S. 886 (1945). 
though the tide did not turn instantaneously and equally in all places. ${ }^{19}$ If particular aspects of a shareholder's interest were constitutionally immune from any substantial change, except on his consent, which is the "vested rights" doctrine, they would be no more subject to change by mere difference in technical procedure, whether or not accompanied by a cash-appraisal right. He would be constitutionally entitled to keep what he had and could not be forced to give it up for another form of property corresponding in another person's judgment to the value of what he liked. Logically, he could no more be forced to exchange his interests for cash than he could be forced to exchange them for stock. So when it was held constitutional to force an unwilling shareholder to accept money in a merger, it was only a question of time before logic and common sense would sweep away purely formal distinctions and, thus, eliminate what still remained of "vested rights."

The real determinants of the courts' new approach to changes in the corporate structure are not, however, to be found in the rationale of the early cases. The reasoning of Havender ${ }^{20}$ was as technical as Keller. ${ }^{21}$ But technicalities can be a workmanlike device for opening a passage when that is being done for the first time. After Havender, we cannot doubt that the door was opened to remain open. The courts, at last, had recognized that a new world had grown up outside the courtrooms that could no longer be measured in the old Euclidian terms. The new spaces of the industrial world, like those of the physical, required a new philosophical formulation. Relativity was as applicable to one as to the other.

Instead of a neighborhood railroad which could not be extended except on unanimous consent, ${ }^{22}$ the new systems ran from the Atlantic to the Mississippi.or thence to the Pacific, often with bus and air subsidiaries. The neighborhood power house had become an electric utility system serving a connected territory in several states. The neighborhood flour or textile mill had become a vast organization owning its sources of raw material throughout the world, manufacturing wherever economy indicated, and selling in the national market and beyond.

The statistical measure of these changes, ideally, would be a cumulative summary of the family corporations of fifty years ago, for example, that are now owned by the public, contrasting their assets, earnings, and number of stockholders at that earlier time with the present. But those figures are inaccessible. The pace of change can be illustrated, however, in other ways. The number of companies with securities listed on the New York Stock Exchange, which presupposes public distribution, has substantially tripled since the end of $\mathrm{IgI}_{3}$, increasing from an estimated $35^{\circ}$ at that time to IIO5 on August 3I, 1957. During this period, the number of listed shares increased from $151,000,000$ at the end of 1913 , to 808,000,000 at the beginning of 1929 , and thence to 4,719,000,000 on August 3r, 1957. Between the last two dates, their

${ }^{10}$ A more detailed analysis of the judicial decisions is made in Gibson, The Virginia Corporation Law of 8956,42 VA. L. REv. 445, 603, 606-08 (1956).

${ }_{20}$ Federal United Corp. v. Havender, 24 Del. Ch. 318, xI A.2d 33x (Sup. Ct. 1940).

${ }^{21}$ Keller v. Wilson \& Co., 21 Del. Ch. 391, I90 Atl. I1.5 (Sup. Ct. 1936).

${ }^{32}$ See Zabriskie v. Hackensack \& N.Y.R.R., I8 N.J. Eq. I78 (Ch. I867). 
aggregate market value increased from $\$ 71,000,000,000$ to $\$ 218,000,000,000$. This is undeniably an important segment of the economy. Particularizing, we can take the twenty American corporations that are most widely owned by the public today and trace their growth since rgr3 in the following tables.

TABLE A

Total Assets Per Books

(in millions)

\begin{tabular}{|c|c|c|c|}
\hline Company & $1913^{23}$ & $1929^{24}$ & $1957^{25}$ \\
\hline 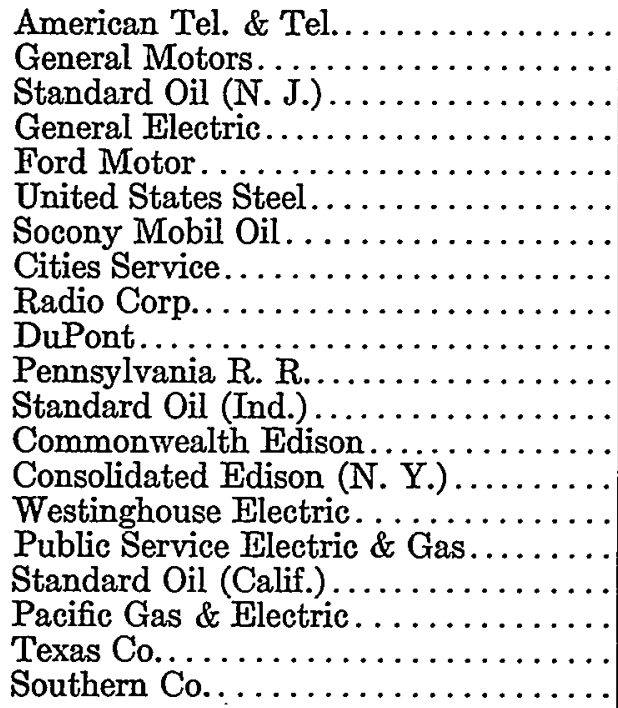 & $\begin{array}{r}656 \\
58 \\
a \\
144 \\
a \\
1,800 \\
94 \\
\mathrm{~b} \\
\mathrm{~b} \\
74 \\
940 \\
49 \\
88 \\
164 \\
83 \\
\mathrm{c} \\
88 \\
204 \\
68 \\
\mathrm{c}\end{array}$ & $\begin{array}{r}\$ 4,228 \\
1,325 \\
1,767 \\
492 \\
a \\
2,286 \\
815 \\
1,090 \\
117 \\
542 \\
2,078 \\
697 \\
376 \\
699 \\
254 \\
\mathrm{c} \\
605 \\
454 \\
527 \\
\mathrm{c}\end{array}$ & $\begin{array}{r}\$ 17,678 \\
6,826 \\
8,712 \\
2,361 \\
3,114 \\
4,074 \\
3,105 \\
1,279 \\
721 \\
3,552 \\
2,991 \\
2,535 \\
1,460 \\
1,829 \\
1,401 \\
1,061 \\
2,246 \\
2,146 \\
2,729 \\
1,037\end{array}$ \\
\hline
\end{tabular}

Key: a-not published

b-company not in existence

c-not separately available because part oi a holding company system

d-reflects divestment of utility properties

The revenues collected are a more realistic measure of their participation in the economy.

This is a different world, indeed. To look only at the first two, a service enterprise that "was being paid by the economy in the order of $\$ 215,000,000$ in 1913 (and paying out correspondingly for labor, capital, plant) had grown to a $\$ 1,000,000,000$ size in $\mathrm{r} 929$ and has grown beyond the $\$ 5,000,000,000$-size today; and a manufacturing enterprise, merely a starter in 1907 , exceeded $\$ 1,000,000,000$ in 1929 and exceeds $\$$ ro,000,000,000 today.

The number of shareholders in these same corporations reveals in another way how far they have moved from the relationship of neighbors or partners.

${ }^{2 s}$ Poor's Manual of Industrials (rgi4); Poor's Manual of Public Utilities (I914).

${ }^{24}$ Moody's Industrials (I933); Moody's Public Utzlities (I933); Moody's Railronds (1930).

${ }^{26}$ Moody's Industrials (1958); Moody's Public Utilities (1958); Moody's Railroads (1958). 
TABLE B

Gross Revenues

(in millions)

\begin{tabular}{|c|c|c|c|}
\hline Company & $1913^{26}$ & $1929^{27}$ & $1957^{28}$ \\
\hline 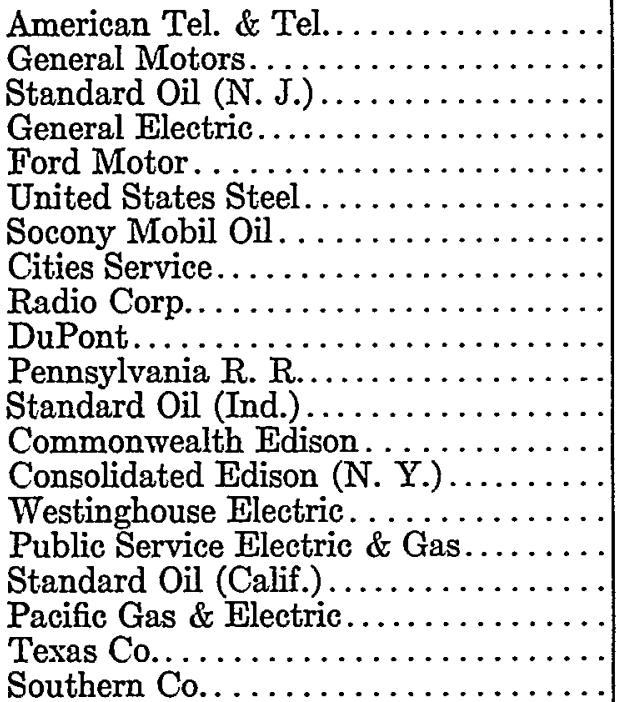 & $\begin{array}{c}\$ 215 \\
{[8]^{\mathrm{e}}} \\
\mathrm{a} \\
106 \\
\mathrm{a} \\
796 \\
{[16]^{\mathrm{e}}} \\
\mathrm{b} \\
\mathrm{b} \\
27 \\
185 \\
\mathrm{a} \\
17 \\
14 \\
40 \\
\mathrm{c} \\
{[19]^{\mathrm{e}}} \\
16 \\
26 \\
\mathrm{c}\end{array}$ & $\begin{array}{c}\$ 1,071 \\
1,504 \\
1,523 \\
415 \\
a \\
1,494 \\
{[64]^{\mathrm{e}}} \\
184 \\
159 \\
82 \\
182 \\
{[85]^{\mathrm{e}}} \\
83 \\
223 \\
216 \\
\mathrm{c} \\
70 \\
64 \\
213 \\
\text { c }\end{array}$ & $\begin{array}{r}\$ 6,313 \\
11,085 \\
7,830 \\
4,336 \\
5,771 \\
4,414 \\
2,976 \\
1,046^{\circ} \\
1,176 \\
2,000 \\
987 \\
2,010 \\
380 \\
553 \\
2,009 \\
322 \\
1,651 \\
501 \\
2,344 \\
255\end{array}$ \\
\hline
\end{tabular}

Key: a-not published

b-company not in existence

c-not separately available because part of a holding company system

d-reflects divestment of utility properties

e-after expenses

TABLE C

Number of Shareholders ${ }^{29}$

\begin{tabular}{|c|c|}
\hline Company & 1957 \\
\hline American Tel. \& Tel.. & $1,490,000$ \\
\hline General Motors. . . . . & 640,473 \\
\hline Standard Oil (N. J.). & 403,000 \\
\hline General Electric.... & 366,524 \\
\hline Ford Motor..... & 298,918 \\
\hline United States Steel. & 257,997 \\
\hline Socony Mobil Oil.. & 181,605 \\
\hline Cities Service Co.. & 174,496 \\
\hline Radio Corp..... & 158,397 \\
\hline DuPont & 153,832 \\
\hline Pennsylvania $R$. $R$. & 144,468 \\
\hline Standard Oil (Ind.) & 143,225 \\
\hline
\end{tabular}

${ }^{20}$ Poor's Manual of Industrials (I914); Poor's Manual of Public Utilities (I9I4).

${ }^{27}$ Moody's Industraals (I933); Moody's Public UtTlities (I933); Moody's Ratlroads (r930).

${ }^{28}$ Moody's Industriats (1958); Moody's Public Uttrities (1958); Moody's Railroads (I958).

20 The Exchange (published by New York Stock Exchange), March 1957, p. 7 . 


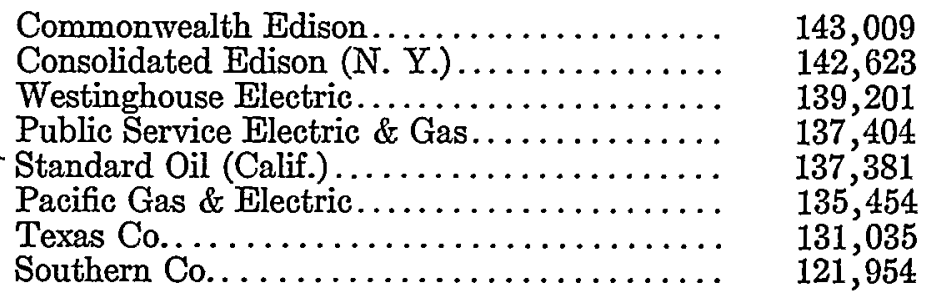

At the present time, 8,600,000 people own shares in American business corporations. ${ }^{30}$ This represents a thirty-three per cent increase in the four years from I952 to $195^{6.31}$ Over two-thirds of these holders have incomes of less than $\$ 7,500$ a year. And the end is not yet. It has been estimated that during the decade ending in 1965 , an increase of roughly forty per cent will be realized in each of gross national product, public construction, disposable income, and consumer expenditures. ${ }^{32}$ This will require large increases in the physical plant of the economy. It will also require large-scale financing. It is estimated that during the decade ending in 1965 , American business corporations will need to raise "\$60 billions in outside equity money" for the enlargement of their plant and equipment, or three times the volume of new stock financing in the last ten years. ${ }^{33}$ Financing of this extent will require resort to the American people for additions to their individual investments.

These developments are propelled by the "deepest force of the time," which is the aspiration of the masses of the people for increased participation in the new products made available by science. ${ }^{34}$ This necessitates production and distribution in the largest volume. This has been possible only though the astonishing growth of the American business corporation. It has grown in size, spread throughout the United States, overrun its political boundaries, and enlisted the investments of increasing millions of citizens. It continues to grow by its own concentration of ability and method. Thus, it has become a "political institution,"35 "a quasi-governing agency."36 It is now a participant in the administration of affairs in a degree of importance having both national and international interest. This diversification of activity is essential not only to business, but also to government itself, since no modern state can hope to defend itself within the resources of its own political frontiers. ${ }^{37}$

In such a perspective, the old reasoning of private contract law has lost its savor, just as the feudal words "quamdiu," "dummodo," etc. seem out of fashion now.

${ }^{20}$ New York Stock Exchange, Who Owns American Business?.12-13 (1956).

${ }^{31}$ Id. at 5.

${ }^{32}$ Projection by the Joint Committee on the Economic Report, charted in PooR's InvestMent ADVISORY SURVEY 274 (1957).

${ }^{33}$ Address by G. Keith Funston, New Steps to Strengthen the Rights of Stockholders, General Management Conference of the American Management Association, June 4, 1957.

${ }^{34}$ Adolph A. Berle, JR., The 20th Century Capitalist Revolution 164 (1954).

${ }^{35} I d$. at 60 .

so Ibid.

${ }^{37}$ See Anolph A. Berle, Jr., Times of Crisis x6-17 (1957). 
As a corporation loses its neighborhood aspect and takes on the character of a political institution, it is of national concern that the corporation have flexibility to adapt itself to new challenges and new problems arising in our ever-changing. economy. It becomes necessary that rearrangement of its capitalization with the shifting tides of business need should be accomplished like other practical decisions. This means that changes can be made by the majority within the procedural limitations set up by statute to safeguard the minority from abuse. No veto by a small group can be tolerated. However suitable the rule of unanimity might be for a partnership, it is wholly unsuited to political institutions. ${ }^{38}$

In formal terms, this means the disappearance of the doctrine of "vested rights." And now, where a statute authorizes change, no limit is to be drawn on the power of the corporation to make changes of any nature and extent in the rights of shareholders, so long as the requisite proportion of the affected class assent. Conversely, modifications of class-shareholder rights will present no justiciable question, except where noncompliance with the statute or fraud is alleged. This is on the simple ground that if the amendment is authorized by statute, the legislature has spoken and judges should not deny its effect by substituting their own notions of public policy. ${ }^{39}$ The logic of this approach is just as applicable to the recapitalization or extinguishment of preferred arrears ${ }^{40}$ as it is to the modification of other shareholder "rights," though in this particular area, the old rule has been given up with special reluctance because of the semblance of retrospective change. ${ }^{41}$ No provision of the federal or state constitutions forbids giving full effect to such legislation. This has long been recognized in New York. ${ }^{42}$ It is increasingly the prevailing view elsewhere. ${ }^{43}$ Indeed, a survey of judicial history since Havender reveals no landmark decision reinvigorating the old doctrine of "vested rights."

${ }^{38}$ Medieval Poland required unanimous consent for the choice of a king. But in consequence, the electors spent all their time maneuvering for decision, without opportunity to attend to the business of the state.

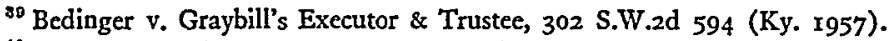

${ }^{\circ}$ Western Foundry Co. v. Wicker, 403 IIl. 26I, 85 N.E.2d 722 (1949); Anderson v. Cleveland-Cliffs. Iron Co., 87 N.E.2d 384 (Ohio C.P. 1948), 18 U. Cin. L. REv. 539 (1949). See also Waterbury, Corporations-Dividends-Elimination of Dividend Accumulation by Direct Charter Amendment, 48 Mirch. L. Rev. 657 (1950).

12 Janes v. Washburn Co., 326 Mass. 356, 94 N.E.2d 479 (1950), 30 B.U.L. Rev. 574 (1950), 37 VA. L. Rev. 3 I 8 (I95X); Schaad v. Hotel Easton Co., 369 Pa. 486, 87 A.2d 227 (I952).

${ }^{2}$ Garzo v. Maid of the Mist Steamboat Co., 303 N.Y. 516, I04 N.E.2d 882 (1952); Liebschutz v. Schaffer Stores Co., 276 App. Div. I, 93 N.Y.S.2d 125 (4th Dep't 1949), aff'd, 279 App. Div. 96, 108 N.Y.S.2d 476 (3d Dep't I95Y); Arstein v. Robert Reis \& Co., 77 N.Y.S.2d 303 (Sup. Ct. 1948), aff'd, 273 App. Div. 963, 79 N.Y.S.2d 314 (Ist Dep't I948); McNulty v. W. \& J. Sloane, I84 Misc. 835, 54 N.Y.S.2d 253 (Sup. Ct. 1945); Hinckley v. Schwarzchild \& Sulzberger Co., I07 App. Div. 470, 95 N.Y. Supp. 357 (Ist Dep't 1905). See also Anderson v. International Minerals \& Chem. Corp., 295 N.Y. 343, 67 N.E.2d 573 (1946); Davison v. Parker, Austin \& Lipscomb, Inc., 285 N.Y. 500, 35 N.E.2d 618 (I94I).

${ }^{4}$ Metzger v. George Washington Memorial Park, Inc., 380 Pa. 350, r10 A.2d 425 (1955); French v. Cumberland Bank \& Trust Co., I94 Va. 475, 74 S.E.2d 265 (1953); Donohue v. Heuser, 239 S.W.2d 238 (Ky. I95I); Sherman v. Pepin Pickling Co., 230 Minn. 87, 41 N.W.2d 57I (1950); Western Foundry Co. v. Wicker, 403 Ill. 260, 85 N.E.2d 722 (1949); Franzblau v. Capital Securities Co., 2 N.J. Super. 517, 64 A.2d 644 (Ch. I949); Dratz v. Occidental Hotel Co., 325 Mich. 699, 39 N.W.2d 34I (1949); Porges v. Vadsco Sales Corp., 27 Del. Ch. 127, 32 A.2d I48 (Ch. I943); Hubbard v. Jones. 
This is not to say that shareholder interests have lost all protection under the Constitution. They retain such protection as comparable types of property enjoy. But it does mean that there is no constitutional requirement for unanimous assent for changes of class shareholder rights. Assuming the reservation of a power to amend, the assent of the statutory majority is sufficient and binding on all nonassenting members of the class, regardless of the times when the stock was issued and the statute enacted. Since these statutes were enacted to keep the agencies of business healthy and adaptable to changing business conditions, it is important that the same rules apply uniformly to all corporations, without regard to the time of their organization and financing. ${ }^{44}$

The disappearance of "vested rights" in the sense of a requirement for unanimous consent before any change of important right is even more conspicuous in the pattern that has been followed by all new legislation in the last ten years. Beginning in 1946 , thirteen states have adopted complete new corporation codes or largely amended their existing law. In every instance, these new provisions purport to authorize any kind of change, whatever its nature or extent, when approved by a specified proportion of the shareholders. In most instances, stockholders are protected against changes of a substantially adverse nature by requiring the assent of two-thirds of the affected class, voting separately, even though not otherwise entitled to vote at all by the terms of the charter. There is great merit in requiring that at least two out of every three adversely affected stockholders must favor the change. This high requirement will exert an influence on the formulation of the plan and, when satisfied, provides a strong practical assurance of the will of the owners. Where a two-thirds vote is required, none of the new statutes provides the alternative of a cash appraisal. Among the new statutes, that extraordinary remedy is confined to those that do not require a class vote or, if any, require no more than a majority assent. ${ }^{45}$

\& Laughlin Steel Corp., 42 F. Supp. 432 (W.D. Pa. r94I); Winfree v. Riverside Cotton Mills Co., 113 Va. 717, 75 S.E. 309 (1912). And see HenRy W. Ballantine, Corporations 648-50 (rev. ed. 1946); Gibson, supra note I9, at 603-I9; Dodd, Accrued Dividends in Delaware Corporations from Vested Right to Mirage, 57 Harv. L. Rev. 894 (1944); Latty, Fairness-The Focal Point in Preferred Stock Arrearage Elimination, 29 VA. L. REv. I, 5 I (1942); Dodd, Dissenting Stockholders and Amendments to Corporate Charters, 75 U. PA. L. REv. 585, 723 (I927).

The states still applying the old doctrine are exceptional. E.g., Schaffner v. Standard Boiler \& Plate Iron Co., I50 Ohio St. 454, 83 N.E.2d 192 (1948); Wheatley v. A. I. Root Co., 79 Ohio App. 93, 72 N.E.2d 482 (1945), modified on appeal, 147 Ohio St. 127, 69 N.E.2d 187 (1946); Clark v. Henrietta Mills, 219 N.C. I, I2 S.E.2d 682 (194r); Patterson v. Henrietta Mills, 219 N.C. 7, 12 S.E.2d 686 (r94I); Patterson v. Durham Hosiery Mills, 2I4 N.C. 806, 200 S.E. 906 (1939).

14 Thus, the Virginia Code Commission said: "It is important in the public interest that the same rules apply to present corporations and securities as to new ones and thus that the Act apply in full force to corporations existing and securities outstanding at its effective date." CODE COMmssion or Virginia for Revision of the Laws Relating to Corporations, Report 94 (I955).

${ }^{45}$ The cash-appraisal remedy is a substantial handicap to management. See, e.g., New York Bar Association Commitree on Corporation Law, Report 75, 80 (1957). The protection it affords the shareholder is often largely formal, and it is generally thought "unsatisfactory." See Dodd, Fair and Equitable Recapitalizations, 55 Harv. L. REv. 780, 816 (1942); ct. Note, Interplay of Rights of Stockholders Dissenting from Sale of Corporate Assets, 58 CoLvm. L. REv. 251 (1958). But cf. Skoler, Some Observations of the Scope of Appraisal Statutes, I3 Business LAwYer 240, 245-53 (1958). 
The outlines of this new legislation are shown in the following table. The Model Act referred to is that prepared by the Committee on Corporate Law of the American Bar Association (the latest revision being in 1957).

TABLE D

NEW LegisLation

\begin{tabular}{|c|c|c|}
\hline State & Date & Nature \\
\hline Kentucky & 1946 & $\begin{array}{l}\text { "Any change in preferences, special rights or } \\
\text { powers" upon a two-thirds class vote, without } \\
\text { any alternative. Ky. REv. STAT. } \$ 271.445 \text {. (1955) }\end{array}$ \\
\hline Oklahoma & 1947 & $\begin{array}{l}\text { Specific enumeration of all known changes, upon } \\
\text { a majority vote of the affected class, with cash } \\
\text { appraisal right. OKLA. STAT. tit. 18, } \$ \$ 1.153-57 \\
(1951) \text {. }\end{array}$ \\
\hline Maryland & 1951 & $\begin{array}{l}\text { Specific enumeration of all known changes, upon } \\
\text { a two-thirds vote, without a class vote unless so } \\
\text { provided by charter but with right of cash ap- } \\
\text { praisal. MD. ANN. CoDE. art. } 23, \S \S 10-11 \text { (1951). }\end{array}$ \\
\hline Wisconsin & 1951 & $\begin{array}{l}\text { The Model Act (specific enumeration of all } \\
\text { known changes, upon a two-thirds class vote, } \\
\text { with no alternative). WIs. STAT. } \$ \$ 180.51-52 \\
\text { (1955). }\end{array}$ \\
\hline Oregon & 1953 & $\begin{array}{l}\text { The Model Act, as above. ORE. REv. STAT. } \\
\$ \$ 57.355-65 \text { (Supp. 1955) }\end{array}$ \\
\hline Florida & 1953 & $\begin{array}{l}\text { Any change in "preference, or ... rights", upon } \\
\text { a majority class vote, with no alternative. FLA. } \\
\text { STAT. } \$ 608.18 \text { (1955). }\end{array}$ \\
\hline District of Columbia & 1954 & $\begin{array}{l}\text { The Model Act, as above, except the clause } \\
\text { authorizing the cancellation of rights to accrued, } \\
\text { but undeclared, dividends is omitted. D. C. } \\
\text { CoDE ANN. } \$ 29-921 \mathrm{f}-22 \text { (Supp. 1956). }\end{array}$ \\
\hline Texas & 1955 & $\begin{array}{l}\text { The Model Act, as above. TEX. Bus. Corp. Act. } \\
\text { arts. } 4.01-.03 \text { (1956). }\end{array}$ \\
\hline North Carolina & 1955 & $\begin{array}{l}\text { Specific enumeration of all known changes, upon } \\
\text { a majority class vote, with cash appraisal. N. C. } \\
\text { GEN. STAT. } \$ \$ 55-99-101 \text { (Supp. 1955). }\end{array}$ \\
\hline Virginia & 1956 & $\begin{array}{l}\text { The Model Act, as above. VA. Codr ANN. } \\
\S \S 13.1-55-57 \text { (Supp. 1956), as amened, Va. Acts } \\
1958 \text {, c.564. }\end{array}$ \\
\hline North Dakota & 1957 & $\begin{array}{l}\text { The Model Act, as above. N. D. Laws 1957, } \\
\text { c.102, } \$ 54-56 \text {. }\end{array}$ \\
\hline Alaska & 1957 & The Model Act, as above. Alaska Sess. Laws \\
\hline Colorado & 1958 & $\begin{array}{l}\text { The Model Act, as above. Colo. Laws 1958, S. B. } \\
14 \text { (effective January } 1,1959 \text { ). }\end{array}$ \\
\hline
\end{tabular}

All these statutes confer the power of amendment in the broadest possible terms. While in two instances, the words are general in nature, they are, nevertheless, unlimited. The others take pains to enumerate all familiar types of modifications of class rights that had been reviewed by the courts, thus foreclosing any possibility of a 
restrictive interpretation. It is noteworthy that none confers or contemplates any power of review, whether administrative or judicial, on grounds of fairness. This was for no want of example or precept. Examples are available, but unappealing. ${ }^{40}$ And precept was profuse, though unconvincing. ${ }^{47}$

This decade of legislation, in which about a quarter of the states rewrote their corporation statutes deliberately to preclude review for "fairness," followed immediately upon a decade which had been largely occupied in enforcing a "fairness" test in corporate rearrangements of wide diversification. Fairness in railroad reorganizations under section seventy-seven of the Bankruptcy Act or chapter fifteen had been litigated endlessly. ${ }^{48}$ Experience with industries under section $77 \mathrm{~B}$ or chapter ten had been comparable. ${ }^{49}$ Even the expert administrative agencies had found difficulties under section eleven of the Public Utility Holding Company Act ${ }^{50}$ and under section five of the Interstate Commerce Act.51 While such may be the rocky road to follow

"Administrative review is available uniquely in California by the definition of "sale" in the Blue Sky law. Cal. Corp. CODE $\$ 25009$. An example of the uncertainties that result is afforded by the pending litigation of Western Airlines with the California Commissioner over the charter amendment approved by a $59 \%$ vote of its stockholders to eliminate cumulative voting. Western Airlines is a Delaware corporation; but in view of this litigation arising out of California law, the amendment has becn withheld. See Seward, The Movement for Modernization of State Corporation Laws, Commercial and Financial Chronicle, July II, 1957. Judicial review is available uniquely in Nebraska, under a statute permitting any adversely-affected stockholder to apply to any court of competent jurisdiction to enjoin amendments "on the grounds of fraud or unfairness," with the requirement that the court enjoin the amendments if the proponents "fail to show that, to a reasonable probability, they are fair, just, and equitable." Neb. Rev. Stat. $\$ 21-1162$ (1954). Court review is also available in England by statute permitting any adversely-affected shareholder to apply to a court, which may disallow the amendment "if satisfied, having regard to all the circumstances of the case, that the variation would unfairly prejudice the shareholders" of that class. Companies Act, I948, 1 I \& 12 Geo. 6, c. 38, $\$ 72$.

\$7 See, e.g., Latty, Exploration of Legislative Remedy for Prejudicial Changes in Senior Shares, 19 U. CHI. L. REv. 759 (1952); Walter, Fairness in State Court Recapitalization Plans-a Disappearing Doctrine, 29 B.U.L. Rev. 453 (1949); Note, 69 Harv. L. Rev. 538, 543 (1956). The more thoughtful commentators recognized that "fairness" is too vague and diffcult to apply in practice. Sec Becht, Alteration of Accrued Dividends, 49 MrCH. L. REv. 363, 565, 588-92 (1951); Becht, Corporate Charter Amendments, Issues of Prior Stock and the Alteration of Dividend Rates, 50 Colum. L. REv. 900 (1950); Becht, Changes in the Interests of Classes of Stockholders by Corporate Charter Amendments, Reducing Capital and Altering Redemption, Liquidation and Sinking Fund Provisions, 36 Cornell L.Q. I (1950); Note, 37 CoRNelL L.Q. 768 (1952).

${ }^{8}$ E.g., Insurance Group Comm. v. Denver \& R.G.W.R.R., 329 U.S. 607 (1947); RFC v. Denver \& R.G.W.R.R., 328 U.S. 495 (1946); Group of Institutional Investors v. Chicago, M., St.P. \& Pac. R.R., 3 I8 U.S. 523 (r943); Ecker v. Western Pac. R.R., 318 U.S. 448 (1943). For a discussion of the difficulties involved in evaluating railroad assets in a reorganization, a process which must underlic any attempt to ascertain the "fairness" of any proposed plan, see Wren, The Valuation of a Railroad in Reorganization, 58 CoLum. L. REv. 316 (1958).

${ }^{40}$ See Consolidated Rock Products Co. v. DuBois, 312 U.S. 510 (1941); Case v. Los Angeles Lumber Products Co., 308 U.S. 106 (1939). The Securities and Exchange Commission is still redefining the standards. See In the Matter of Geren River Steel Corp., Corp. Reorg. Release No. 105, Jan. 24, 1957, p. 21 .

${ }^{50}$ See SEC v. Central-Illinois Securities Corp., 338 U.S. 96 (1949); Otis \& Co. v. SEC, 323 U.S. 624 (1945).

E1 See Schwabacher v. United States, 334 U.S. 182 (1948). The difficultics in applying a test of "Fairness" to corporate readjustments do not result from the imprecision of that term alone. They are inherent in the intrinsic vagueness of any standard, however defined, with which one attempts to weigh complex economic conjectures. Thus, the same uncertainties have been met under $\$ 20 \mathrm{~b}$ of the Interstate Commerce Act, where the plan must be found to be "in the best interests" of each class. 
where creditors can not be satisfied or special public policies are to be enforced, the states have chosen a different road for the modification of class shareholder rights in the case of the ordinary solvent corporation. The reason has primarily been the belief, characteristically American in nature, that it ought to be possible to consummate practical transactions without having to stop first to conclude exhaustive examinations into matters that are largely indeterminable. Three contributing reasons may be noted. As the rate of economic change has quickened and corporations have grown in size, the practical pressures for completing a plan expeditiously have increased. The same growth has been accompanied by a dispersal of stock ownership that has tended to separate management from domination by a cohesive group of stockholders. This has reduced the dangers of insider preference. Finally, the question of fair treatment involves a balancing of different investment attributes in the light of prospective future earnings, which is not pre-eminently adapted to the judicial expertise.

The extent to which the decisions and statutes discussed above cover corporate business in the United States can be judged from the following table identifying the ten states whose corporations had the greatest combined assets. This table is based on a study of the 600 largest industrial, merchandising and utility companies in the United States. It shows that of those covered in the study, 498 were incorporated in these ten states. ${ }^{52}$

The modern view is, thus, securely established that a two-thirds vote of the affected class will bind the minority, as under the Model Act.

\section{II}

\section{The Scope of Judicial Review Today}

Though the old "vested rights" decisions were cast in terms of power, judges apparently were really troubled by the question of fairness of treatment. When they denied the existence of the power of a corporation to effect a proposed change on grounds that seemed technical, often they were motivated by the belief that the plan was unfair and should not be allowed, usually for the reason that management was apparently dominated by a cohesive majority group that was attempting to cut down the rights of a senior class or a minority of the same class without sufficient

The Boston and Maine plan for the disposition of preferred arrears was first turned down by the Commission and then, on a more vigorous presentation, approved. Boston and Maine R.R. Securities Modification, 282 I.C.C. 750 (1953). The Missouri-Kansas-Texas Railroad has not yet succeeded. Its first plan was rejected by the Commission. Missouri-Kansas-Texas R.R. Sccurities Modification, 275 I.C.C. 499 (1950). It then submitted a second plan on Dec. 24, 1952. I.C.C. Finance Docket No. 18006. This plan was amended on Jan. 25, 1955, in an unsuccessful attempt to meet the Commission's objections. The second plan was then withdrawn. (Order unreported.) A third proposal was then filed on May I, 1957, In the Matter of the Application of the Missouri-Kansas-Texas R.R. Co., I.C.C., Finance Docket No. 19760 , and an examiner's report has recommended that it be approved with modifications. The N.Y. Times, Nov. $x$, 1957, p. 39, col. 4-5.

${ }^{52}$ Compiled by James F. Spoerri from the supplement edition Fortune of July 1956, in JornT Comm. to Study Revision of Corporate LATw, Interim Report 6I (New York Legislative Document No. 17, 1957). 
TABLE E

Corporate Business

\begin{tabular}{|c|c|c|}
\hline State & No. of Corporations & Assets (in millions) \\
\hline 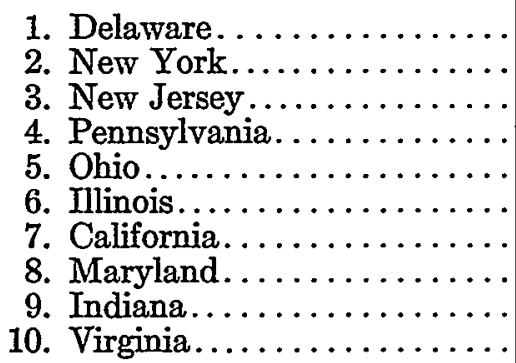 & $\begin{array}{r}202 \\
85 \\
45 \\
45 \\
36 \\
29 \\
13 \\
18 \\
11 \\
14\end{array}$ & $\begin{array}{r}\$ 55,424 \\
40,991 \\
22,768 \\
11,659 \\
7,859 \\
6,402 \\
4,864 \\
3,777 \\
3,528 \\
2,476\end{array}$ \\
\hline
\end{tabular}

compensation or necessity. There are some opinions, indeed, that expressly went on grounds of fairness. ${ }^{\text {t3 }}$

But "fairness" is an elusive standard. Where the statutory power exists, there is no clear and certain test by which the chancellor can allow its exercise for some purposes and disallow its exercise for others. The quest for "fairness" also leads the chancellor into new fields where he is normally not expert. It places on him the heavy burden of solving complex economic problems in order to formulate a judgment as to the soundness, and hence the fairness, of the proposed amendment. The efforts to apply a deliberate test of "fairness" were, thus, gradually abandoned. They finally disappeared with the "vested rights" doctrine. It is now recognized that where the legal power for a recapitalization exists, the question of fairness is not one for judicial examination:

The fairness or unfairness of corporate action may not be considered where that action is in exercise of a power conferred upon the corporation by the Act under which it was organized. ${ }^{54}$

... the minority shareholder may not obtain relief in equity where his claim is based upon unfairness rather than fraud. ${ }^{55}$

Does it follow that no judicial review is permissible? By no means. Unfairness

${ }^{53}$ E.g., Kamena v. Janssen Dairy Corp., I33 N.J. Eq. 214, 3 I A.2d 200 (Ch. 1943), aff'd per curiam, 134 N.J. Eq. 359, 35 A.2d 894 (Ct. Err. \& App. 1944). And see Wessel v. Guantanamo Sugar Co., 134 N.J. Eq. 27I, 35 A.2d 215 (Ch. 1944), aff'd sub nom. Murphy v. Guantanamo Sugar Co.s 135 N.J. Eq. 506, 39 A.2d 43I (Ct. Err. \& App. 1944).

6. Franzblau v. Capital Securities Co., 2 N.J. Super. 517, 528, 64 A.2d 644, 649 (Ch. 1949).

${ }^{65}$ Matteson v. Ziebarth, 40 Wash.2d 286, 297, 242 P.2d 1025, 1033 (1952). Sec also Dratz v. Occidental Hotel Co., 325 Mich. 699, 39 N.W.2d 34I (1949); Liebold v. Inland S.S. Co., 82 F.2d 351 (7th Cir. I936); Katz v. R. Hoe \& Co., 199 Misc. 459, 103 N.Y.S.2d 106 (Sup. Ct. 1950); Maddock v. Vorclone Corp., I7 Del. Ch. 39, 147 Atl. 255 (Ch. I929); Barrett v. Denver Tramway Corp., 53 F. Supp. 198, 201 (D. Del. 1944), I46 F.2d 701, 706 (3d Cir. I944); Baker v. Standard lime \& Stone Co., 203 Md. 270, roo A.2d 822 (r953); Hyman v. Velsicol Corp., 342 Ill. App. 489, 97 N.E.2d 122 (1951); Ballantine, op. cit. supra note 43 , at 656 . 
is very different from fraud. Fairness raises a question of judgment, where opinions may differ endlessly, and the average businessman is not particularly equipped to know what someone else might conclude at a later date with further evidence. But fraud raises a question of conscience, where the average businessman is likely to recognize that something is shocking and ought to be illegal, whenever it might be reviewed by a court and whatever might be the further evidence. Such a test is sufficiently definite to be practical, though sufficiently elastic to evolve with changing circumstances. It is in sharp contrast with the roving judgment contemplated by the "fairness" test in reorganization legislation.

Where fraud is alleged, all of the new corporation codes contemplate that the courts shall have jurisdiction, on timely application, to prevent the consummation of a plan. In some statutes, this is express. ${ }^{56}$ In the Model Act and similar legislation, it is equally presupposed.

Where the interests of so many people are involved and the securities are traded on the exchanges, there is an unusually urgent need for prompt action on the part of anyone seeking to prevent the accomplishment of a plan. In the case of most listed securities, a stockholder will have received notice some three or four weeks before the meeting and should know that in the ordinary course, the amendment will be presented for effectuation immediately upon the conclusion of the meeting. Once the plan has been put into effect, it becomes virtually impossible to turn back the clock without hurting the innocent as well as the guilty. For this reason, the doctrines of laches and estoppel should be applied with especial strictness. Those who have reason to object and know it but do not speak seasonably should not be heard subsequently. Ordinarily, this should mean action before the issuance of the amendment.

What then is fraud? There is no definition in the statutes. That is left, and rightly so, to the equity judges, who have always used it as a flexible means of preventing a wrong of such nature as to shock the conscience. Whatever the changing circumstances may be, the equitable doctrine of fraud will be available, though it remains to be formulated by actual decisions as controversies take shape. This necessary and unavoidable imprecision, however, makes it a dangerous weapon, and one that judges should use with great restraint. In the past, the term has acquired reasonably identifiable boundaries. When applied to determine the legality of changes in corporations, it should be kept within these limits. A few things would, thus, seem expectable.

Manifestly, "fraud" should not be used as a means of nullifying the recentlyenacted statutes. It cannot be found in a modification, as such, of a class shareholder's rights that is in terms permitted by the statute. To take an extreme case, a total cancellation of accrued unpaid dividends on preferred stock is one of the changes specifically authorized in the Model Act and most of the recent statutes. It

\footnotetext{
${ }^{{ }^{50}}$ Sce, e.g., VA. CODE ANN. $§$ I3.I-125 (Supp. 1956), restricting all review of Corporation Commission action to direct appeal, "except for fraud."
} 
should not be possible for the courts to hold such an amendment, in and of itself, fraudulent, since it is not in their province to substitute their view of public policy for the one adopted by the legislature. ${ }^{57}$ An exception might well exist, as indicated below, if the particular circumstances were such as to disqualify the vote as an authentic expression of class assent. But it is to be remembered that however the concept of fraud may evolve, it is still something different from unfairness. Since the pattern of recent legislation deliberately withholds court review for unfairness, the judges should be vigilant to see that they do not actually exercise such a jurisdiction under the name of "constructive fraud" or other vague metaphors of the fraud idea.

Affirmatively, it can be said with some confidence that as judges are accustomed to look with greatest favor on equality as a touchstone of equity, so inequality of treatment among members of the same class is the plainest badge of fraud. As long ago as I9I9, the Southern Pacific Company, upon the reorganization of an indirect subsidiary, caused the accomplishment of a plan by which the minority stockholders could obtain shares in the new company only upon paying an assessment of $\$ 7 x .40$ per share, while the Southern Pacific was allotted all the stock in the new company for an assessment of no more than $\$ 26$ per share plus a guarantee in respect to the new bonds and an underwriting commitment in respect to all the shares. The court sustained a subsequent complaint by minority shareholders as to the allocation of the new stock. It said that when a majority (here a single company) exercises control, "it occupies a fiduciary relation toward the minority," and thus concluded that ${ }^{59}$

... the minority may not be excluded from a fair participation in the fruits of the sale.... The wrong lay not in acquiring the [new] stock, but in refusing to make a pro rata distribution on equal terms among the old ... shareholders.

This principle applies equally where shareholders seek a preference before creditors. $^{60}$ It applies also to beneficial incidents of the stockholder interest, even though not strictly a part of the assets held by the corporation, as where two preferred stockholders, the only ones to attack a reorganization plan, purported to appeal for the common benefit of their class and then, after the expiration of the appeal period, settled for a substantial payment. What the appellants received "in excess of their own interest as stockholders was not payment for anything they owned," but rather for settlement of litigation affecting equally all other preferred stockholders, from which it follows that the "fruit properly belongs to all." They were compelled, therefore, to make a pro rata contribution to all the other holders of the same class. For similar reasons, it has been held that preferential treatment for certain stockholders to induce their assent to a merger would constitute fraud justi-

\footnotetext{
${ }^{67}$ Bedinger v. Graybill's Executor \& Trustee, 302 S.W.2d 594 (Ky. 1957).

${ }^{58}$ Southern Pacific Co. v. Bogert, 250 U.S. 483 (rgrg).

${ }^{60}$ Id. at $487-88,492$.

${ }^{60}$ Pepper v. Litton, 308 U.S. 295, 306-12 (1939).

${ }^{a x}$ Young v. Higbee Co., 324 U.S. 204, 213-14 (1945).
} 
fying an injunction against the merger, unless the treatment were made available equally to all. ${ }^{62}$

This fundamental principle of equal treatment for all members of the same class is related to a further principle against duality of interest. The simplest case is to suppose that the owner of all the common stock is also the owner of two-thirds of the preferred and, thus, assents to an amendment canceling preferred arrears without any compensation. Whatever he gives up in his capacity as a preferred shareholder comes to him as the common shareholder-not only that, indeed, but also what the other preferred shareholders lose as well. Here is a conflicting motive, extrinsic and contrary to the expectable interests of the preferred as a separate class, that, as anticipated in the reference above, invalidates the class vote as an authentic expression of class choice and, thus, makes inoperative the prime safeguard afforded by the statute.

It is plain that a director is a fiduciary for the corporation and its stockholders. ${ }^{63}$ Majority stockholders are not, by mere reason of their holdings, automatically trustees and, indeed, ordinarily remain free to vote their shares in any way they may wish. ${ }^{64}$ But they may be made to share the fiduciary responsibilities of directors where the directors are put in office by them, especially if acting, as a cohesive group. ${ }^{65}$ If so, duality of interest, by one or the other, leads quickly to fraud.

A suggestive and arguable illustration is supplied in the attempt of the Seagrave Corporation to acquire a subsidiary from another corporation. There were seven directors of Seagrave. Of these, four had been put in office by a small group of controlling stockholders for whom the plan provided an option of selling their shares to the dominant stockholder of the selling corporation at a premium of onethird above the current market. This preferential option was not available to the Seagrave's minority shareholders. The other three directors were top management officers, who were in danger of losing their positions under the present control, but who were assured of continuation in office by the dominant stockholder of the selling corporation, who was, through these arrangements, simultaneously acquiring control of Seagrave. This was, indeed, a cloudy picture.

On attack by a minority stockholder of Seagrave, a district court enjoined the plan on the ground that each group of directors had a substantial personal interest of conflicting nature which precluded an exercise of independent judgment on the merits of the plan. ${ }^{60}$ An appeal by Seagrave was very nearly successful on the ground that the proxy statement made a full disclosure of the preferential option and also of the inclination of the new owners to continue top management. Agree-

09 Matteson v. Ziebarth, 40 Wash.2d 286, 297, 242 P.2d 1025, 1033 (1952).

${ }^{63}$ Pepper v. Litton, 308 U.S. 295, 306 (r939).

ox Baker v. Standard Limestone \& Stone Co., 203 Md. 284, 285, 100 A.2d 822, 829 (1953).

${ }^{\circ 5}$ Lebold v. Inland S.S. Co., 82 F.2d 35x, 353-54 (7th Cir. T936); Pepper v. Litton, 308 U.S. 295, 306 (1939). In close corporations, the personal relationships between stockholders may involve special elements of trust and confidence, and in such cases, a fiduciary relation is easier to establish. Helms v. Duckworth, 249 F.2d 482 (D.C. Cir. I957).

${ }^{60}$ Mount v. Seagrave Corp., II2 F. Supp. 330 (S.D. Ohio r953). 
ing also that the economic fairness of the plan was not open to judicial examination and that the terms of the plan were not so oppressive that they could be called fraudulent in themselves, the court of appeals, nevertheless, affirmed on the ground that the personal interests of the directors at stake "deprived the stockholders of that impartial, unprejudiced action which the fiduciary relationship required." Calling this "constructive fraud," the court affirmed the injunction.

This case emphasizes the statutory function of the directors in making the initial proposal of the plan to the shareholders. That submission undoubtedly involves the responsibility of recommendation, even though the words of the Model Act do not require anything except the adoption of a resolution "setting forth the proposed amendment" for submission at a meeting of the shareholders. ${ }^{08}$ And some states have spelled out this inferential responsibility of recommendation in their statutes. Thus, Virginia requires that the resolution be one "setting forth the proposed amendment, finding that it is in the best interest of the corporation and directing that it be submitted. . .."60

In the Seagrave case, however, since the only two elements of conflicting interest, the premium and the employment, were clearly shown in the proxy statement, the case is an extreme one and merits criticism. Other courts would have decided the other way. ${ }^{70}$ As a general rule, that seems the right course, because the full disclosure gives a substantial minority of the stockholders the power to reject the plan. There seems no public policy for denying the owners the right to assent, if they choose to do so with full notice. With regard to the inequality of treatment, which was the basic ground of the decision, the court, at most, could have conditioned its injunction on refusal to open up the preferential offer in such a way as to make it equally available to the minority. But, it should. be recognized that this is a jurisdiction to be sparingly exercised, since it means that the court is making a new bargain in lieu of what the principals have accepted. With regard to the dual interest of the three directors, which was a secondary ground for the decision, the court's decision is shortsighted, in that it may make any action impossible in particular situations, and improvident, in that it pays no heed to the possible benefits of the plan. The minority might well have been better off with the plan than without it, even though not quite so well off as the majority. They may not be benefited by setting the whole plan aside, even though a particular litigant might benefit in a tactical sense. Salving the conscience of the court or vindicating the theoretical correctness of a single shareholder's objection is not as important as protecting the general interests of the shareholders, the corporation, and the public.

Where there is a conflicting interest of such substantial nature and effect as to negate the statutory process of director recommendation and class assent, the appropriate remedy is to put the proponents on proof that the plan is fair. This is the

\footnotetext{
${ }^{87}$ Seagrave Corp. v. Mount, 2I2 F.2d 389, 393 (6th Cir. 1954).

${ }^{\circ 8}$ Modex Business Corporatton ACt $\$ 54$ -

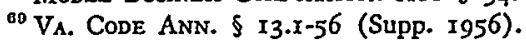

${ }^{70}$ See Matteson v. Ziebarth, 40 Wash.2d 286, 242 P.2d 1025 (1952).
} 
rule applied by some courts in similar situations where directors have other interest. $^{71}$ It has special applicability in cases where the plan itself involves a conflicting interest of directors or, more importantly, of shareholders. This has been recognized: ${ }^{72}$

Plaintiffs invoke the settled rule of law that Hilton as a majority stockholder of Mayflower and the Hilton directors as its nominees occupy, in relation to the minority, a fiduciary position in dealing with Mayflower's property. Since they stand on both sides of the transaction, they bear the burden of establishing its entire fairness, and it must pass the test of careful scrutiny by the courts.

Such proof would normally follow the general pattern of the reorganization cases. First, that there is some corporate need for the recapitalization and that the particular plan is feasible. Second, that the treatment accorded the respective classes is fair. This requires the court to weigh the investment attributes of the old stock according to their probable realization in the light of reasonably foreseeable future earnings, and hence to appraise "the current worth of [the] promise"73 or its "investment value."74 This is to be compared with the prospective economic or investment worth, similarly ascertained, of the differing attributes of the new securities or other consideration proposed. No dollar figures are necessary as to the old and the new. ${ }^{75}$ Rather, a judgment conclusion is contemplated to the general effect that the new treatment will represent "the equitable equivalent" of the old or its "economic equivalent." This is not to be ascertained on a spot-cash basis, but on the basis of the prospective future that has such a degree of likelihood within such an expectable period of time as normally to merit recognition by a reasonable investor. In all this field, there are legal standards to apply, but the material and the measures for weighing it are financial and economic in nature.

The occasions for judicial review of the elements of fraud that have been so far mentioned may now be summarized in classical, though necessarily general, words of the Supreme Court. It said that judicial review begins where legal power is exceeded or "a fraudulent transaction" is theatened and, thus, by way of illustration: $:^{78}$

... where the board of directors, or a majority of them, are acting for their own interest, in a manner destructive of the corporation itself, or of the rights of the other shareholders; ...

Or where the majority of the shareholders themselves are oppressively and illegally pursuing a course in the name of the corporation, which is in violation of the rights of the other shareholders, and which can only be restrained by the aid of a court of equity.

${ }^{71}$ E.g., Fountain v. Oreck's, Inc., 245 Minn. 202; 7x N.W.2d 646 (1955).

${ }^{72}$ Sterling v. Mayflower Hotel Corp., 33 Del. Ch. 293, 298, 314, 93 A.2d 107, I10, II9 (Ch. r952).

${ }^{73}$ Schwabacher v. United States, 334 U.S. I82, 199 (r948).

${ }^{76}$ In the Matter of Green River Steel Corp., Corp. Reorg. Release No. 105, Jan. 24, 1957, p. 2 r.

${ }^{76}$ Group of Institutional Investors v. Chicago, M., St.P. \& Pac. R. Co., 328 U.S. 523, 565-66 (I943).

${ }^{70} \mathrm{Ibid}$.

${ }^{77}$ Schwabacher v. United States, 334 U.S. $x 82,200$ (1948).

${ }^{78}$ Swanson v. Traer, 354 U.S. II 4, II7 (r957), quoting from Hawes v. Oakland, 104 U.S. 450, 460 (1881). 
The next element that will be given greatest weight in shifting a question of fraud is the sufficiency and fullness of the information given to stockholders. As already indicated, it would be too extreme to say that disclosure preeludes the possibility of fraud. The sole owner of all the common stock and two-thirds of the preferred voting to cancel without compensation all preferred arrears for his own benefit should be held fraudulent, however boldly his purpose be preclaimed in a proxy statement. But in all cases of alleged fraud, there can be no doubt that disclosure is the strongest antiseptic. The more fully the owners are informed as to the meaning and consequences of their choice, the more meaningful is their vote as an authentic expression of ownership preference and, thus, the fuller the satisfaction of the statutory policy. At the same time, the fuller is the protection that will be accorded management. The basic importance of adequate information is recognized in the stock exchanges: ${ }^{79}$

Shareowners must be assured of adequate and timely information on which to base their vote-and in a larger sense-on which to base their investment decisions.

Where no proxy statement is required by the governing statute, the mere requirement of notice of the meeting is not to be read so broadly as to have the same effect. It means notice in the classical sense, and no more. But this means only that a meeting will not be held invalid for lack of notice where the meager notice of classical proportions has been given. If any substantial question of fraud arises, a wholly different standard comes into play at once, and an adequate exposition of the nature and effect of the change may well be required not to satisfy the statutory standard, but to repel the charge of fraud.

Turning now from interpretation to policy, it is desirable that legislation go on further to require this same degree of information from the business managers in any proposal for recapitalization. The affairs of corporations have become so technical and so remote from the usual shareholder that there is increasing need for proxy statements that clearly reveal the substance of the proposal. Where there is no such requirement, one should be supplied. Suitable information is required by the Securities and Exchange Commission with respect to all securities listed on a national securities exchange. ${ }^{80}$ Its administration of that law, as of the Securities Act of $1933{ }^{81}$ has undoubtedly been a great national benefit. But there are many other corporations of general investment interest that have no securities listed on a national securities exchange and, thus, are not subject to the Proxy Regulation. Bills have been pending unsuccessfully in the Congress since 1949 to extend the proxy power of the Securities and Exchange Commission over unlisted securities. If confined to corporations of sufficient size, this is a meritorious proposal that

${ }^{79}$ Funston, stupra note 33 , at 4 . X-r 4 .

${ }^{80}$ Securities Exchange Act $\S 14,48$ STat. 895 (1934), 15 U.S.C. $\S 78 \mathrm{n}$ (1952); SEC Regulation ${ }^{81} 48$ STAT. 74, 15 U.S.C. $\$ \$ 77$ a-aa (1952). 
should be enacted. The latest bill, as introduced by Senator Fulbright, ${ }^{82}$ would have applied to every issuer with total assets exceeding $\$ 2,000,000$, where its equity securities are held of record by more than $75^{\circ}$ persons. The studies of the Securities and Exchange Commission indicate that in this form, the bill would have applied to approximately 1,200 corporations with assets aggregating $\$ 35,000,000,000^{83} \mathrm{As}$ reported out by the Committee, the bill is confined to corporations with at least $\$ 10,000,000$ of assets and I,000 shareholders. As so amended, the bill would reach approximately 600 unlisted companies and assure all their stockholders of the substantial, pertinent, and timely information that has resulted from the Commission's healthy administration of section fourteen of the Securities Exchange Act ${ }^{84}$ with respect to listed companies. There can be no doubt that when a corporation reaches this size and involves this many people, it becomes a matter of general consequence, rather than of a purely local interest. It is also clear that with the increasing importance given class voting in modifications of class shareholder rights, adequate information on the nature and effect of the plan grows in public importance. The requirements of the Proxy Regulation are enforceable by judicial review and injunction before the meeting..$^{85}$

A more extreme proposal has also been under consideration by the Securities and Exchange Commission involving the repeal of its Rule 133. Since the original enactment of the Securities Act of 1933, it has been generally understood that modifications of shareholder rights through voting procedures sanctioned by state statute, like amendments and mergers, were not "sales" within the terms of the Act. This basic conclusion as to the interrelation of federal and state legislation has not had official standing in proportion to its importance. Though covering the field of Securities and Exchange Commission responsibilities, it was originally embodied only in an instruction to Form E, applicable to issues of securities in certain forms of reorganization. This was applied in most situations, however, though not with absolute uniformity. When Form $\mathrm{E}$ was repealed, the rule was not recorded anywhere and remained only as an unwritten tradition that was respected in the administration of the 1933 Act. In the course of the admirable revisions recently made by the Commission to systematize all its rules and put of record all traditional practices, Rule 133 was adopted as a precise and official statement of this practice.

${ }^{82}$ S. I168, 85th Cong., Ist Sess. (I957), introduced Feb. II, 1957. See also, Hearings before a Subcommittee of the Committee on Banking and Currency of the Senate on S. 594, S. 1r68, and S. 16or, 85th Cong., Ist Sess. (1957); SEC, Report on S. 2054 to the Committee on Banking and Currency of the Senate, 84th Cong., 2d Sess. (1956); SEC, Supplementary Report on S. 2054 to the Committee on Banking and Currency of the Senate, 85th Cong., Ist Sess. (1957); Meeker, Current Trends in the Federal Securities Laws, I2 THE Recond 347, 360 (1957); Meeker, Current Proposals to Amend the Federal Securities Laws, ${ }_{3} 3$ BusINEss LAwYER 379, 386-87 (1958).

${ }^{83}$ Testimony of $\mathrm{J}$. Sinclair Armstrong on May 20, r957, Hearings, supra note 82, at 10-37.

84 48 STAT. 895 (1934), I5 U.S.C. $\$ 78$ n (1952).

${ }^{85}$ SEC v. May, I34 F. Supp. 247 (S.D.N.Y. I955), aff'd, 229 F.2d I23 (2d Cir. 1956); SEC v. Okin, 58 F. Supp. 20 (S.D.N.Y. 1944); SEC v. O'Hara Re-Election Comm., 28 F. Supp. 523 (D. Mass. 1939). Cf. SEC v. Transamerica Corp., 67 F. Supp. 326 (D. Del. 1946); modified on other grounds, $x 63$ F.2d 5 II (3d Cir. I947), cert. denied, 332 U.S. 847 (1948). But cf. Howard v. Furst, I40 F. Supp. 507 (S.D.N.Y. 1956), 238 F.2d 790 (2d Cir. 1956), cert. denied, 353 U.S. 937 (1957). 
The recent proposal for its early repeal is primarily designed to make the registration provisions of the 1933 Act applicable to mergers and amendments, since the Commission feels that secondary distributions have occurred in connection with some mergers contrary to the registration policies of the Act. But the proposed remedy is far wider than the evil. It would give most recapitalizations the legal status of sales, even though no new investment is to be made by the shareholder. Such widespread opposition developed, ${ }^{86}$ that the Commission has deferred any formal action on Rule 133 pending further study and has announced that it would deal with distributions that appear to violate the registration policies of the Act on a case-by-case basis. ${ }^{87}$

III

\section{The Resulting Responsibilities}

-When recapitalizations are needed, management plays a crucial role in crystallizing the will of the owners. As steward for the absentee owners, it is for management to formulate a plan. This usually requires negotiation with underwriters, or institutional purchasers, or other corporations that may be included in a unification. The initial choice of approach, differently affecting the interests of shareholders, is largely irrevocable once made, because a negotiation, however fluid, seldom flows backward. -At each stage of the formulation of the plan, new responsibilities for fair treatment of all interests rest on management as a result of the semifinal effect of shareholder choice under modern legislation. New responsibilities for full and fair disclosure also result directly from this same circumstance, for the vote of the owners is meaningful as an expression of their real desire only if they are adequately informed.

There are massive sanctions to enforce these new responsibilities, though for the :most part, they are beyond the process of a court and not utilizable in ordinary litigation. True enough, at the technical level, disclosure is the most powerful defense against a claim of fraud. Many things that would be fraudulent if unsaid are not when explained, and the informed choice of a statutory majority will bind all conclusively. The things that would remain fraudulent even though fully ex-

\footnotetext{
${ }^{80}$ See SEC, Report of Proceedings on Proposed Revision of Rule I33 Under the Securities Act of I933 app. 9, at II-12, 17-20,44,47, 93, 120 (1957).

${ }^{87}$ Securities Act Release No. 376r, March 19, 1957; Demmler, Developments in Federal Regulation Securities, 12 Business LAWYER 470, 476 (1957). Where the new securities are acquired with a view to distribution, the Commission has asserted that the exemption is unavailable. Securitics Act Relcasc No. 3846, Oct. 10, 1957, although it may be observed that this presupposes a "purchase" from the issuer, despite the fact that by Rule $x 33$ there has been no "sale." See Orrick, Sonie Interpretative Problems Respecting the Registration Requirements under the Securities Act, 13 BusINEss LAWYER 369 (1958). There is an important difference where the securityholder is already invested in the venture. Thus, the British Companies Act, I948, II and 12 GEo. 6, c. 38, \$38, specifying the contents of a prospectus, has no application to a pro rata offering of new shares to existing shareholders. Colc, Morley, and Scott, Corporate Financing in Great Britain, 12 Business LAwYer 324, 356-59 (1957). In the case of a reclassification, not only has the shareholder already invested, but he is also not asked to supply additional capital, though admittedly his rights are being changed in substance and the proxy requirements are, therefore, particularly salutary. For arguments favoring repeal of Rule 133, sce Sargent, A Review of the No-Sale Theory of Rule 133, I3 Business LAWYER 78 (1957); for arguments opposing, see Throop, In Defense of Rule 133, 13 Business Lawyer 389 (1958).
} 
plained are very few and exceptional. So also, fairness in the substance of the plan has an eventual relation to reviewability: when it passes the point of a difference of judgment and becomes shocking to the conscience of the chancellor, it is at the door of fraud. But the principal sanctions lie further on.

At a deeper level, management impairs its standing with the shareholders when it proposes an unfair plan or proposes any plan without adequately disclosing its nature and effect. Either course is a perilous development for all concerned. As for the stockholders, since they must look to management for the direction of operations and the development of any necessary recapitalization plans, they must either sell their stock, or go to the trouble of protesting, or take steps to throw management out of office. As for management, the loss of shareholder trust and confidence terminates their satisfaction in supervising the corporate affairs and, at a further degree, may terminate their job as well. These consequences are not automatic. But they are likely. And some of the largest oaks fall in unexpected winds. When stockholders are restless and many shares are in temporary hands, any one who knocks loudly on the door may find himself in.

Still more fundmental is the sanction imposed by society itself. Corporations are allowed to manage their own business only if, by and large, they manage it well. They are too large and too important to have their way on any other terms. The rule that a two-thirds assent binds the whole class has come into being as the healthy and practical rule for the modern corporation. It deserves to prevail and to have the fidelity of management that will maintain it. But should abuses become prevalent, the rule will be changed. And unless the corporation continues to do a better job than government could, society. will interpose to protect its essential interests.

This is not mere theorization on the familiar theme of power entailing responsibility. It represents the sensitive insight and governing motive of leading corporate managements. This was well illustrated at the latest annual meeting of Standard Oil Company of New Jersey. Here is the same company, it will be remembered, that once had pioneering days of its own and was accused of frontier manners at that time, was subsequently disintegrated under the Sherman $A c t,{ }^{88}$ and is now multiplied beyond any dream and one of our best citizens. First, as to the power of this great corporation, which goes beyond physical possessions, the chairman said: ${ }^{89}$

.. . Jersey is a leading example of democratic enterprise. It strengthens the American way at home and provides an example of its benefits to our friends abroad. And because energy is an essential to defense, the company is an integral part of the shield that guards all free men from tyranny.

Then as to the responsibilities that flow from this position, the chairman said: $:^{90}$

Jersey feels a responsibility and has a determination to maintain scientific and technical

${ }^{88}$ Standard Oil Co. of New Jersey v. United States, 22 I U.S. I (I9II).

${ }^{80}$ Standard Oil Company of New Jersey, 75th Annual Meeting 7 (I957).

${ }^{\mathrm{D}} \mathrm{Ibid}$. 
leadership; to prove itself a good citizen; to establish sound human relations. It believes it must live by principles of ethics and morality which form the basic rules of society; and do its part in establishing those rules of conduct in its business relations throughout the world.

Applying this philosophy to operations, the president said::1

... [N]o commercial organization, particularly one of Jersey's size, can exist without creating certain social influences and, thereby, acquiring responsibilities beyond those of a purely business nature. These responsibilities will certainly grow in the future, as Jersey's normal growth continues. ...

Applying this to the particulars, the president gave special emphasis to the 156,000 employees and concluded: ${ }^{22}$

In addition, Jersey has civic responsibilities to the various communities where its affliates operate, financial responsibilities to the educational institutions from which it draws many of its key employees, and-under many categories-responsibilities to governments.

With regard to the latter, Jersey's stature entitles it to add that these include "the responsibility to help and to participate in the development of friendly foreign nations." ${ }^{33}$ It has, indeed, more earthly power than many formal sovereignties that sit in the United Nations.

This epitomizes the best thinking in contemporary corporate management. In this new world, the feudal "diversities" are no longer meaningful. The class shareholder rights are not fixed, but relative, and it is better in the public interest that this be so. But, without regard to the technical processes of the courts and looking to broader social necessities that are translated into legislation and judicial process whenever necessary, management has new responsibilities in consequence. Most directly these are to the shareholders as analyzed above. But that is not all. With great new size and power, there also come great new responsibilities toward all the groups who are affected by the corporate undertaking. Thus, in a very real sense, management bears a share of the responsibility for maintaining that miracle of a dynamic, expanding, and socially-respected economy that supports the American way of life.
${ }^{81} I d$. at 14.
${ }^{88} I d$. at I4.
${ }^{09} 1 d$. at 15. 